\title{
Professionalism Enhancement of Ece Tutors Through K13 Learning Devices Production Training In Cibitung Tengah Village, Bogor Regency
}

\author{
Yenina Akmal $^{1}$, Hikmah ${ }^{1}$, Ika Subekti ${ }^{1}$, Agus Kurniawan ${ }^{1}$, Ichtineza Halida Hardono ${ }^{1}$ \\ ${ }^{1}$ Departement of PG-PAUD, Faculty of Education, State University of Jakarta, Jl. Rawamangun Muka Raya, \\ East Jakarta, 13220
}

Author for CoresspondenceEmail: yenina.akmal@yahoo.com

\begin{abstract}
The presence of Early Childhood Education (ECE) tutor in Cibitung Tengah Village Tenjolaya District Bogor Regency is really needed for early childhood in order to become a guide in the ECE institutions. The problem occurred is that the average education level of ECE tutor is diverse, from Middle School, High School, Associate Degree, and Bachelor Degree. In this condition, we can say that those ECE tutors had not had the knowledge and insight about the ECE, namely the 2013 Curriculum, the ECE concept, and the learning devices. Training, along with the research about the role of those training itself, are need to be done in order to answer this question for increasing the knowledge and insight of ECE tutor using action research method. The results showed the enhancement of conducted training, including the enhancement of interest and motivation to develop their knowledge and insight about the ECE. Extended with the existence of WhatsApp group as a platform for communication between ECE tutors and UNJ researchers in the efforts to enhance the professionalism of ECE tutors, in the context of mentoring, ECE Tutors in the Cibitung Tengah, Tenjolaya Village were also involved in the learning devices production training in order to apply the religious moral concept to the ECE in the teaching and learning process at the UNJ and also to observe Ceria Daycare of the Department of ECE, Faculty of Education, UNJ.
\end{abstract}

Keyword - Early Childhood Education (ECE), 2013 Curriculum, Learning Devices

\section{INTRODUCTION}

\begin{abstract}
A child in early childhood is defined as a human in the period of golden age, occurring before the age of eight. It is called the golden age since it is the most important period to develop every aspect of development (cognitive, social-emotional, moral religion, language, motoric, art: 2013 Curriculum). The development process at this period must go through some stages assisted by adults, both parents at home [1] and ECE tutors in ECE institutions [2]. However, the process is inseparable from the human resources of educators within the Early Childhood Education Institute because human resources are a central factor in an institution or organization. Entering the third millennium,
\end{abstract}

Indonesia is faced with the challenge of preparing the community for a new era, namely globalization that touches all aspects of life. Statistics Indonesia data showed that from 260 million Indonesian citizens, $90 \%$ of the population are Muslims. Hence, modern perspective for Muslims is required, including the field of education adjusted to the faith. Thus, professional ECE tutors are needed as early childhood educators.

As written in the Regulation of the Minister of Education and Culture Number 137 by 2014 about the Standards of Educators and Education Personnel in article 24 which says 1) Early childhood educators are professionals who are tasked with planning, implementing learning, and evaluating learning outcomes, as well as providing guidance, training, care, and protection; 2) Early childhood educators consist of ECE tutors, support tutors, and young support tutors. Therefore, early childhood educators are divided into 3 qualifications, namely ECE Tutor who has a diploma of Associate Degree (D4) or Bachelor Degree (S1) in ECE or Psychology; The Support Tutor who has a diploma of Associate 
Degree (D2) in Kindergarten Education; Young Support Tutor who has a high school diploma and certificates of ECE trainings/educations/courses from competent government institutions. It is intended that early childhood educators (ECE tutors) should not only teach based on the compassion and experience as they did at home but also have the insight and knowledge about early childhood education according to the needs of these early childhoods.

The characteristics of professional ECE teachers/tutors are teachers who have academic qualifications (Regulation of the Minister of Education and Culture Number 137 by 2014) and have 4 profession competencies which include pedagogical competence [3;4], personality competence, professional competence and social competence [5]. The design of early childhood learning activities, based on the Regulation of the Minister of Education and Culture Number 137 by 2014 in Article 12 Act 2 said that learning planning includes: a) Semester Program; b) Weekly Learning Implementation Plan (RPPM); and c) Daily Learning Implementation Plan (RPPH). Whereas in Article 13 it is said that the implementation of learning is carried out through interactive, inspirational, fun, contextual and child-centered play to actively participate and provide freedom for initiative, creativity and independence in accordance with the talents and interests, and physical and psychological development. Thus, the process of education and learning in early childhood should be done with the aim of providing concepts that are meaningful for children through real experience. Only real experience allows children to show optimal activities and curiosity and placing the position of educators as guides, mentors, and facilitators for early childhood [6].

In order to get a good tutor for early childhood, it is necessary to conduct a training in making learning devices using the 2013 curriculum-based learning tools, since this curriculum is the latest curriculum in use. According to Riyanto [7], learning devices served as signs for teachers to carry out classroom learning. Specifically, learning device functions are 1) As a guide to learning for teachers, 2) As a benchmark for the success of classroom learning, 3) As a medium to improve teacher professionalism, and 4) As a tool to facilitate teachers in facilitating learning. Learning devices include Syllabus, Effective Week Details, Semester Program, Annual Program, KI/KD Mapping, Learning
Implementation Plans, Educational Calendar, and Evaluation Tools.

2013 Curriculum (K-13) about Early Childhood Education consists of seven components, namely: (1) Basic Curriculum Framework, (2) Curriculum Structure, (3) Guidelines for Early Detection of Child Development, (4) Guidelines for Development of Education Unit Level Curriculum, (5) Guidelines Learning, (6) Assessment Guidelines, and (7) Educator's Guide Books. The ECE 2013 curriculum refers to the National Standards for Early Childhood Education. The characteristics of the 2013 ECE curriculum are (1) optimizing the child development which includes the aspects of religious and moral, physical-motoric, cognitive, language, social-emotional, and art values which are reflected in the stability of attitudes, knowledge and skills competencies, (2) using thematic learning with a scientific approach to providing educational stimuli, (3) using authentic assessment in monitoring child development, and (4) empowering the role of parents in the process [8].

The fact showed that many ECE tutors were housewives or Family Welfare Programme cadres with various levels of education ranging from S1, high school and even from junior high school. This condition also occurs in Cibitung Tengah Village, where the level of education owned by residents generally only reaches elementary school to junior high school, although there are some who have a Bachelor's degree as well as a Master. So it is necessary to improve the knowledge and skills of making K-13-based learning devices by conducting a structured mentoring to ECE tutors in Cibitung Tengah Village. This structured mentoring is a process that requires the facilitator to play an active role in arranging guidance, direction, assistance and other technical support to ECE tutors. There are several stages in the mentoring program, namely 1) Field Observation Phase, 2) Field Findings Analysis Phase, 3) Field Needs Analysis Phase, 4) Program Planning Phase, 5) Program Implementation Phase, and 6) Program Evaluation Phase [9].

\section{METHOD}

This research used the action research method. Action Research Method is a method that aims to improve the effectiveness and efficiency of educational practices [10]. The purpose of action research is to learn through actions that then lead to development [11]. The use of the action research 
method was expected that after action was taken, the ECE tutors from 4 PAUDs (ECE), 2 Kindergartens (TK), 1 Raudhatul Athfals (RA) and 1 Quran Kindergarten (TKA/TPA) who do not have the ability and skills about making learning devices will improve their knowledge and skills.

In this research, the target institutions were TK AlGhozali, TK Nurul Anwar, RA Arrahman, PAUD Mutiara Bunda, PAUD Nurul Huda, PAUD AsShidiq, PAUD As - Syifa, and TKA/TPA AlHikmah. The collaborators in this study were the Cibitung Tengah Village Headman and the Cibitung Tengah Village HIMPAUDI Chairman. Mentoring was carried out together with collaborators from the beginning, viz. at the time of observation, intervention in the form of activities 1,2, 3, 4 to 5 .

The sampling method used in this study was purposive sampling technique. The purposive sampling technique is a sampling technique that is carried out by taking subjects that are not based on strata, random and regional, but based on the existence of goals [12]. Data in this study was collected by interview and observation techniques. The interview technique was used as data to obtain complete and deeper results.

\section{RESULTS AND DISCUSSION}

\section{Results Description}

Before carrying out the research in the first cycle, researchers previously carried out pre-research activities. The activities carried out were preliminary observations, met the village headman and the HIMPAUDI chairman to manage the permits, conducting initial interviews and distributing questionnaires to get early ECE tutor knowledge about 2013 Curriculum. The questionnaire aimed to dig the ECE tutors initial knowledge about the 2013 curriculum along with the aspects included in it.

The pre-research activities obtained information that the initial knowledge and skills of ECE tutors in Cibitung Village were at an average percentage of $60.5 \%$. In more detail, the score obtained in the table shows the highest score of 51 so that it reaches a percentage of $68 \%$. This shows that knowledge of the 2013 curriculum is good enough. While for the lowest score is 31 with a percentage of $41.3 \%$. With $71 \%$ percentage achievement agreement to increase the percentage after the action, the score and percentage obtained in the pre-intervention stage became the initial reference for the implementation of activities to improve the knowledge and skills of ECE tutors in Cibitung Tengah Village. Supported by the results of interviews, researchers obtained data that ECE tutors knowledge of the 2013 curriculum was good enough, where many ECE tutors had already attended training on the 2013 curriculum. However, most, even almost all of the ECE tutors were not educators with a Bachelor Degree in Early Childhood Education. Not only that, but the ECE tutors have also never attended ECE basic courses that caused the occurrence of an obstacle to implementing the 2013 curriculum in learning devices. This had become a benchmark for skills in making 2013 curriculum-based learning devices.

From the pre-research scores (pre-intervention), it can be determined that ECE tutors in Cibitung Tengah need to get interventions to improve their knowledge and skills in making 2013 curriculumbased learning devices. The interventions provided were structured mentoring with a material provision, training and focus group discussion (FGD) which were completed with a test to see the increase in knowledge and skills of ECE tutors after structured mentoring was carried out.

The cycle I was carried out after obtaining preintervention data about the knowledge and skills of ECE tutors in developing 2013 curriculum-based learning devices. In cycle I there were several planning actions in the form of material explanation about 2013 curriculum, theme-making training, and theme webbing, FGD on material that had been given and ended with a test. The first action given was aimed at providing knowledge about the 2013 curriculum to ECE tutors as the subject of this research. The activity was followed by training in creating themes and webbing themes to provide skills to ECE tutors in applying the 2013 curriculum in determining and webbing the theme. The activity continued with FGD where ECE tutors could discuss and ask questions from each other and mentors. The activity ended with giving a questionnaire which contained questions related to the material given.

The second action given in the first cycle was the presentation of the material about K-13-based learning devices, training on the making of the Annual Program and the Semester Program, followed by training in making RPPM and RPPH. Aside from providing knowledge about K-13-based learning devices, this action also focused on the skills of learning device preparation which include the making of the Annual Program and Semester 
Program, as well as RPPM and RPPH included in the learning tools. The practical activities carried out were expected to hone the 2013 curriculum application skills in making learning devices.

In Cycle II, ECE tutors were given training materials for the creation of learning media and assessments for early childhood. This activity was carried out with the explanation to the material which was continued with training on learning media and assessment. Activities continued with FGD and tests related to the material. The measurement of percentage achievement in cycle II was done by giving the final test when all the action activities in cycle II had been completed.

\section{Data Analysis}

Quantitative information was obtained from the preintervention phase (cycle I and cycle II). The table 1 shows a significant increase, from the average percentage of pre-intervention data by $60.5 \%$ to $70.9 \%$ in the cycle I and to $83.0 \%$ in cycle II. The average increase achieved in cycle I was $10.4 \%$ and the increase in the cycle II was an average of $12.1 \%$. The total increase in the overall percentage from preintervention, cycle I and cycle II reached $22.5 \%$.

When viewed from the increase in the percentage of each participant, each cycle experienced a positive increase and there was no decrease in the percentage achieved. This showed that the effectiveness of the actions provided has a positive impact, where the knowledge and skills of ECE tutors in Cibitung Tengah significantly increased. This was the base for stopping the action, enough in cycle II. This was because the target achievement of the percentage had exceeded $71 \%$.

Qualitatively, the results of interviews with respondents provided information that the actions in the form of material presentation activities followed by practice and FGD made the knowledge gained more profound and not just a theory. According to respondents, practical and FGD activities given were very positive. This could be seen with the ability to compile learning devices such as annual programs, semester programs, RPPM and RPPH which were increased during practice and FGD. Each respondent practiced the provided material immediately and continued with the results presentation that had been made so that they would be given a response and correction from fellow respondents and the mentors straightaway. More clearly, the improvement of respondents knowledge and skills in the arrangement of 2013 curriculum-based learning devices can be seen in the Fig 1 .

The graph above shows an increase from the preintervention phase (cycle I and cycle II). The blue bars show the percentage at the pre-intervention phase, while the red bars and green bars show the percentage in cycle I and cycle II respectively. The graph above provides information that the increase occurred at all phases and all respondents.

Structured mentoring activities provided through the provision of material, training and practice, FGDs and tests effectively supported the improvement of respondents knowledge and skills in making 2013 curriculum-based learning devices. Some participants who previously did not have knowledge of the 2013 curriculum and learning devices became more insightful. Participants who already have good initial knowledge could develop their skills in developing learning devices through practical activities. This made the respondents who were initially unfamiliar in the preparation of the learning devices became more skilled and could apply their own learning devices in their institutions.

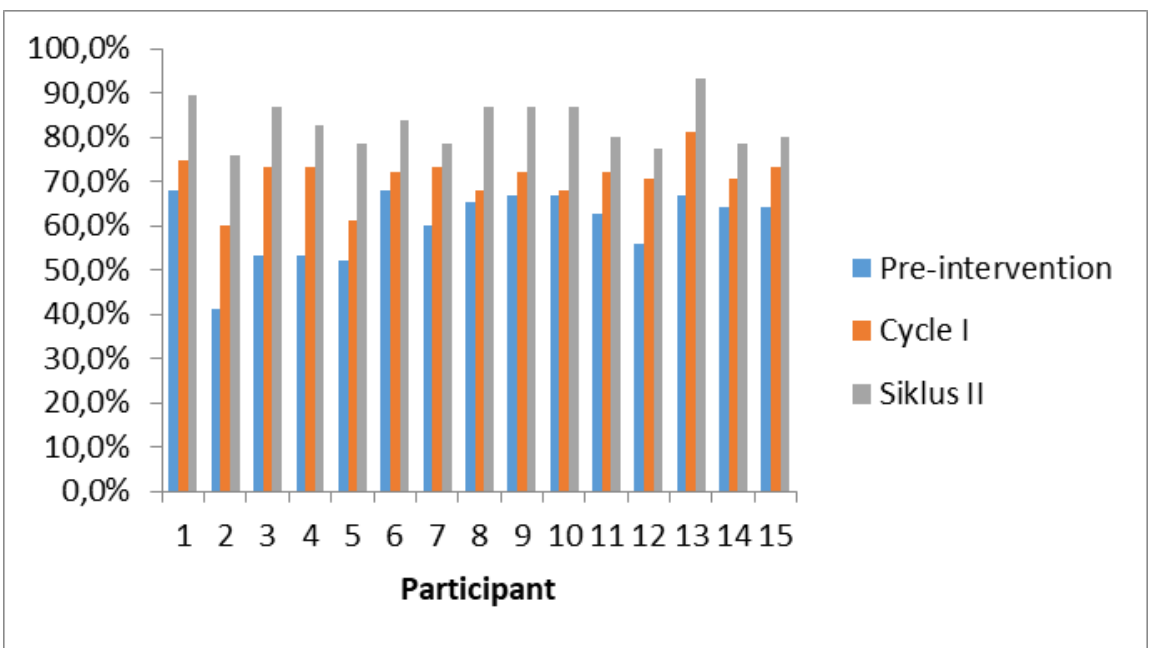

Fig 1. Percentage of Knowledge and Skills Increase of the Respondents in Arranging K-13 Based Learning Devices 
Some indicators such as the knowledge of K-13, knowledge and skills in making learning devices, implementation of learning, knowledge of scientific approaches in K-13, making media and learning resources, as well as evaluating/making AUD assessments had been achieved well by the respondents. The increase that occurred in the preintervention phase (cycle I and cycle II) showed that the indicators set were fulfilled. This showed the success of the intervention provided in improving the knowledge and skills of making 2013 curriculum-based learning devices.

\section{CONCLUSION}

The efforts to increase the knowledge and skills of ECE tutors in Cibitung Tengah Village in making 2013 Curriculum-based learning devices conducted through these two cycles had achieved success marked by exceeding the percentage target of $71 \%$. Structured mentoring activities were successful in making a significant increase in respondents knowledge and skills in making 2013 curriculumbased learning devices. The effectiveness of structured mentoring provided to ECE tutors in Cibitung Tengah had been proven by the significant increase in respondents knowledge and skills reaching $83 \%$. A significant increase allowed respondents to develop the 2013 curriculum in the learning devices in their respective institutions so that the success of early childhood education can be felt by many parties.

Based on the conclusions stated, the researcher gives the following suggestions: 1) The ECE Tutors are expected to develop the knowledge and skills acquired in their respective institutions to support the development of early childhood in all aspects through appropriate learning activities; 2)The Principals of ECE Institutions are expected to facilitate and provide approval in the application of new knowledge obtained by educators in their institutions so that there is continuity between the abilities acquired by educators and policies in institutions; and 3) The local HIMPAUDI is expected to expand cooperation to organize various training to enrich the ability of educators in their region.

\section{ACKNOWLEDGEMENTS}

The research team is very grateful to God for making this research possible. Appreciation and gratitude are extended to the Dean of the Faculty of Education of UNJ for giving the opportunity to conduct this research as a part of Three Principles of Higher Education with the funding from the BLU UNJ in 2018. Furthermore, we would like to thank the Cibitung Village Head who has facilitated this research and the ECE teachers/tutors who have been willing to attend as respondents.

Tabel 1. Percentage of Knowledge and Skills Increase of the Respondents in Arranging K-13 Based Learning Devices

\begin{tabular}{|c|c|c|c|c|c|c|}
\hline \multirow{2}{*}{ Respondent } & \multicolumn{3}{|c|}{ Percentage } & \multicolumn{2}{|c|}{ Percentage Increase } & \multirow{2}{*}{$\begin{array}{c}\text { Total Percentage } \\
\text { Increase }\end{array}$} \\
\hline & Pre-intervention & Cycle I & Cycle II & Cycle I & Cycle II & \\
\hline 1 & $68,0 \%$ & $74,7 \%$ & $89,3 \%$ & $6,7 \%$ & $14,7 \%$ & $21,3 \%$ \\
\hline 2 & $41,3 \%$ & $60,0 \%$ & $76,0 \%$ & $18,7 \%$ & $16,0 \%$ & $34,7 \%$ \\
\hline 3 & $53,3 \%$ & $73,3 \%$ & $86,7 \%$ & $20,0 \%$ & $13,3 \%$ & $33,3 \%$ \\
\hline 4 & $53,3 \%$ & $73,3 \%$ & $82,7 \%$ & $20,0 \%$ & $9,3 \%$ & $29,3 \%$ \\
\hline 5 & $52,0 \%$ & $61,3 \%$ & $78,7 \%$ & $9,3 \%$ & $17,3 \%$ & $26,7 \%$ \\
\hline 6 & $68,0 \%$ & $72,0 \%$ & $84,0 \%$ & $4,0 \%$ & $12,0 \%$ & $16,0 \%$ \\
\hline 7 & $60,0 \%$ & $73,3 \%$ & $78,7 \%$ & $13,3 \%$ & $5,3 \%$ & $18,7 \%$ \\
\hline 8 & $65,3 \%$ & $68,0 \%$ & $86,7 \%$ & $2,7 \%$ & $18,7 \%$ & $21,3 \%$ \\
\hline 9 & $66,7 \%$ & $72,0 \%$ & $86,7 \%$ & $5,3 \%$ & $14,7 \%$ & $20,0 \%$ \\
\hline 10 & $66,7 \%$ & $68,0 \%$ & $86,7 \%$ & $1,3 \%$ & $18,7 \%$ & $20,0 \%$ \\
\hline 11 & $62,7 \%$ & $72,0 \%$ & $80,0 \%$ & $9,3 \%$ & $8,0 \%$ & $17,3 \%$ \\
\hline 12 & $56,0 \%$ & $70,7 \%$ & $77,3 \%$ & $14,7 \%$ & $6,7 \%$ & $21,3 \%$ \\
\hline 13 & $66,7 \%$ & $81,3 \%$ & $93,3 \%$ & $14,7 \%$ & $12,0 \%$ & $26,7 \%$ \\
\hline 14 & $64,0 \%$ & $70,7 \%$ & $78,7 \%$ & $6,7 \%$ & $8,0 \%$ & $14,7 \%$ \\
\hline 15 & $64,0 \%$ & $73,3 \%$ & $80,0 \%$ & $9,3 \%$ & $6,7 \%$ & $16,0 \%$ \\
\hline Average & $60,5 \%$ & $70,9 \%$ & $83,0 \%$ & $10,4 \%$ & $12,1 \%$ & $22,5 \%$ \\
\hline
\end{tabular}




\section{REFERENCES}

[1] M. Amini, 2015, "Profil Keterlibatan Orang Tua Dalam Pendidikan Anak Usia TK", Jurnal Ilmiah VISI PPTK PAUDNI,Vol. 10, No.1.

[2] A. N. Gordon, K. M. Browne, 2014, Beginnings and Beyond Foundations in Early Childhood Education, 9th Edition. America: Wadsworth.

[3] A. L. Mirzagitova, L. G. Akhmetov, 2015, Self - Development of Pedagogical Competence of Future Teacher, Canadian Center of Science and Education, International Education Studies, Vol. 8, No. 3.

[4] M. Barret, M. Byram, I. Lazar, P. MompointGaillar, S. Philippou, 2013, Developing Intercultural Competence through Education. Secretariat General, Directorate General II, Directorate Of Democratic Citizenship And Participation.

[5] W. S. Winkel, 2010, "Psikologi Pengajaran", Yogyakarta: Media Abadi.

[6] Y. Akmal dan N. Pratiwi, 2012, "Ilmu Pendidikan Anak", Jakarta: FIP Press.

[7] A. Riyanto, 2017, "Perangkat Pembelajaran Kurikulum 2013 Lengkap dan Terbaru 2017", Diakses melalui https://www.amongguru. com/perangkat-pembelajaran-kurikulum 2013-lengkap-dan-terbaru-tahun-2017 pada Mei 2018.

[8] I. M. Tegeh, I.N. Jampel, K. Pudjawan, I. K. Sudarma, N. M. Asril, 2016, "Pendampingan Pengembangan Perangkat Pembelajaran Berbasis Karakter Berdasarkan Kurikulum 2013 Paud Bagi Guru TK Negeri Pembina Dan TK Ceria Asih Singaraja", Laporan P2M DIPA UNDIKSHA.

[9] Y. Akmal, 2012, "Program Pendampingan PAUD Di Lembaga PAUD Cendana RW 06 Dan PAUD Cemara RW 07 Kelurahan Kayu Putih Kecamatan Pulo Gadung Jakarta Timur", Jurnal Sarhawita,Volume 9, Nomor 1 , hal $65-69$.

[10] M. Putrawan dan M. Akbar, 2000, Penelitian Tindakan, Jakarta: Universitas Negeri Jakarta, hal. 31.

[11] A. R. Ghani. 2014. Metodologi Penelitian Tindakan Sekolah. Jakarta: PT RajaGrafindo Persada.

[12] B. Joyce, M. Weil, E. Calhoun, 2009, Models of Teaching (Model - Model Pengajaran), Yogyakarta: Pustaka Pelajar. 